\title{
Epoetin $\beta$ pegol (continuous erythropoietin receptor activator, CERA) is another choice for the treatment of anemia in myelodysplastic syndrome: a case report
}

\author{
Tatsuyoshi Ikenoue ${ }^{1,2^{*}}$, Hiroshi Naito ${ }^{2}$, Tetsuya Kitamura ${ }^{2}$ and Hideki Hattori ${ }^{3}$
}

\begin{abstract}
Background: In most patients, anemia is present when myelodysplastic syndrome is diagnosed. Although darbepoetin a is the first-choice supportive therapy for low-risk myelodysplastic syndrome, half of all patients develop a loss of response to darbepoetin a within 12 months. However, few reports have described supportive therapy after the loss of response to darbepoetin a.

Case presentation: We herein present a case involving a 65-year-old Japanese woman with low-risk myelodysplastic syndrome whose erythropoiesis-stimulating agent treatment was switched from darbepoetin a to epoetin $\beta$ pegol (continuous erythropoietin receptor activator) to treat transfusion-dependent anemia. The frequent transfusions required to treat the anemia resulted in transfusion-associated circulatory overload. The transfusion-dependent anemia was initially treated with darbepoetin a, which negated the requirement for transfusion. However, after 12 months of darbepoetin a therapy, the hemoglobin concentration sharply declined. We switched her therapy from darbepoetin a to continuous erythropoietin receptor activator to avoid transfusion. After initiation of continuous erythropoietin receptor activator therapy, the hemoglobin concentration gradually increased and transfusion was not required. At the time of writing, no progression of the anemia had occurred.
\end{abstract}

Conclusions: Although darbepoetin $a$ is the first-choice supportive therapy for low-risk myelodysplastic syndrome, continuous erythropoietin receptor activator might be considered the second-choice therapy.

Keywords: Myelodysplastic syndromes, Anemia, Erythropoietin, Renal dialysis

\section{Background}

Myelodysplastic syndrome (MDS) is a malignant hematopoietic disease. Typical clinical features of MDS include ineffective hematopoiesis, which is caused by excessive premature apoptosis of hematopoietic precursors at disease onset [1]. The most frequently encountered type of cytopenia is anemia, which is present in approximately $70 \%$ of patients at the time of MDS diagnosis [2]. Anemia is also responsible for most symptoms of MDS. Anemia at the time of MDS diagnosis is an important prognostic

\footnotetext{
* Correspondence: ikenoue.tatsuyoshi.4e@kyoto-u.ac.jp

${ }^{1}$ Department of Healthcare Epidemiology, Kyoto University Graduate School

of Medicine and Public Health, Yoshida Konoe-cho, Sakyo-ku, Kyoto 606-8501, Japan

${ }^{2}$ Fujiidera Keijinkai Clinic, 1-2-3 Emisaka, Fujiidera, Osaka, Japan

Full list of author information is available at the end of the article
}

factor according to the Revised International Prognostic Scoring System, which is the major risk classification system for MDS [3]. Transfusion is performed as supportive therapy to manage anemia, which leads to transfusion dependency in $>80 \%$ of patients during the clinical course of MDS [4]. Transfusion dependency during the clinical course is an important independent prognostic factor. Transfusion-related iron overload is a critical condition predisposing to cardiac complications, increased fatigue, and decreased quality of life [3].

In clinical practice, erythropoiesis-stimulating agents (ESAs) are widely used to treat anemia in patients with low-risk MDS to reduce the risk of red blood cell transfusion [5]. The use of an ESA rather than transfusion improves the overall survival of patients with MDS [6-8], 
and patients with MDS who receive ESA therapy reportedly have longer survival times than those who do not receive ESAs $[9,10]$. Darbepoetin $\alpha$ (DPO) is an ESA that reportedly improves the response rate of patients with MDS more than epoetin $\alpha$ and $\beta$ [11-13]. In Japan, the use of DPO in patients with MDS has been covered by medical insurance since December 2014. Of the major responders to DPO, 10 to $50 \%$ experience a loss of response to DPO within 12 months [7, 14-17].

Few reports have described subsequent supportive therapy after the loss of response to DPO. Furthermore, to the best of our knowledge, no study has investigated the use of epoetin $\beta$ pegol (continuous erythropoietin receptor activator, CERA) as supportive therapy in patients with MDS. In this case report, we describe the use of CERA as supportive therapy in a patient with MDS who experienced a loss of response to DPO through a switch from DPO to CERA.

\section{Case presentation}

A 65-year-old Japanese woman diagnosed with MDS by bone marrow aspiration had been treated at a core hospital since 2008. She had refractory anemia as defined by the World Health Organization classification and was categorized in the low-risk group (Int-1) as defined by the International Prognostic Scoring System. A family history of anemia was absent. Our patient is a housewife and a nonsmoker. She is married with one daughter, and lives in an apartment in an urban area. She had a mastectomy of the left breast in 1986 with no recurrence, but no other relevant medical history. However, she developed diabetes in 1991 with resultant renal insufficiency. Her blood sugar control was suddenly aggravated at the time of MDS diagnosis. Hemodialysis had been initiated in January 2015, and she was transfusion-dependent with her hemoglobin concentrations being maintained at $6.5 \mathrm{~g} / \mathrm{dL}$ by transfusion every 7 to 10 days before dialysis initiation. However, the frequent transfusions resulted in congestive heart failure, and she was hospitalized and diagnosed with transfusion-associated circulatory overload. She was transferred to our clinic for maintenance hemodialysis in February 2015. At this point, her serum erythropoietin level was low $(127 \mathrm{mIU} / \mathrm{mL})$, so she began treatment with epoetin $\alpha$ at $9000 \mathrm{IU} /$ week plus DPO at $40 \mu \mathrm{g} /$ week, which are the usual treatment dosages for renal anemia in our clinic. However, her anemia rapidly progressed while receiving ten transfusions during her dialysis sessions until June 2015; this treatment strategy was based on consultations with a hematologist. She continued to be transfusiondependent, even while undergoing dialysis and treatment with a mid-range dose of ESAs. In July 2015, we increased the DPO to $240 \mu \mathrm{g} /$ week to treat the anemia. After 2 weeks of DPO treatment, the anemia had resolved; she no longer needed transfusions and the hemoglobin concentration was maintained at $>10 \mathrm{~g} / \mathrm{dL}$. However, from March 2016 she gradually developed resistance to the DPO treatment, and in July 2016 her hemoglobin concentration rapidly decreased to $6.8 \mathrm{~g} / \mathrm{dL}$. During March 2016, she had no obvious physical or neurological changes, but slight progression of conjunctival anemia. She was not feverous, and her average body temperature was $36.3^{\circ} \mathrm{C}(97.34 \mathrm{~F})$. Additionally, no changes were observed in her blood pressure or heart rate (average blood pressure, 144.0/56.5 $\mathrm{mmHg}$; average heart rate, 60.6 beats per minute (bpm)). She underwent no changes in her medication and noticed no occupational changes associated with the decrease in hemoglobin. In July 2016, she developed a furuncle caused by a Staphylococcus epidermidis infection of her forearm, which was treated by gentamicin sulfate ointment within 5 days. The results of the laboratory findings are shown in Table 1. Differential diagnoses for this decrease in hemoglobin included gastrointestinal bleeding, pure red cell aplasia, infection, and iron deficiency; however, these were ruled out as causes of the decrease. We switched the ESA from DPO to CERA at $250 \mu \mathrm{g} /$ week on 9 August 2016. After switching to CERA, the hemoglobin concentration gradually rose, and our patient no longer needed further transfusions. No progression of the anemia occurred for 1 year, and her hemoglobin concentration was stable at $>10 \mathrm{~g} / \mathrm{dL}$ (Fig. 1).

\section{Discussion}

In the present case, we determined that the cause of the decrease in hemoglobin was not related to progression of MDS, gastrointestinal bleeding, pure red cell aplasia, infection, and/or iron deficiency. Progression of MDS was ruled out by the stability of our patient's white blood cell and platelet counts and lactate dehydrogenase concentration. Gastrointestinal bleeding was ruled out by gastrointestinal endoscopic examination and a fecal occult blood test. Pure red cell aplasia was ruled out by a high number of reticulocytes and the absence of antierythropoietin (EPO) antibody and anti-EPO receptor antibody using a commercial radioimmunoprecipitation assay. Although the sudden onset of DPO resistance is associated with infection, the infection was negligible in the present case (a minor shunt complication that was resolved with antibiotic ointment). Iron deficiency was also ruled out after testing. Hence, this decrease in hemoglobin was considered to be caused by the development of DPO resistance, which can occur during ESA use in patients with MDS.

EPO has been widely used as an anti-anemia agent in patients with end-stage renal disease since 1987 [18]. The introduction of EPO therapy markedly decreased the necessity of transfusion in patients with end-stage renal disease. DPO has a hyperglycosylated structure, giving it a longer elimination half-life and allowing for an extended dosing interval [19]. The most recently 
Table 1 Results of laboratory findings from March 2016

\begin{tabular}{|c|c|c|}
\hline \multicolumn{3}{|l|}{ Before dialysis session } \\
\hline \multicolumn{3}{|l|}{ Complete blood count } \\
\hline White blood cell & 5340 & $/ \mu \mathrm{L}$ \\
\hline Lymphocytes & 18.7 & $\%$ \\
\hline Basophils & 0.4 & $\%$ \\
\hline Eosinophils & 3.4 & $\%$ \\
\hline Neutrophils & 72.6 & $\%$ \\
\hline Monocytes & 4.9 & $\%$ \\
\hline Red blood cell & 334 & $\times 10^{4} / \mu \mathrm{L}$ \\
\hline Hemoglobin & 9.7 & $\mathrm{~g} / \mathrm{dL}$ \\
\hline Hematocrit & 30.8 & $\%$ \\
\hline $\mathrm{MCH}$ & 32.6 & $\mathrm{pg}$ \\
\hline $\mathrm{MCHC}$ & 31.5 & $\%$ \\
\hline MCV & 103 & $f \mathrm{~L}$ \\
\hline Platelet & 10.7 & $\times 10^{4} / \mu \mathrm{L}$ \\
\hline \multicolumn{3}{|l|}{ Serology } \\
\hline C-reactive protein & 0.13 & $\mathrm{mg} / \mathrm{dL}$ \\
\hline Total bilirubin & 0.6 & $\mathrm{mg} / \mathrm{dL}$ \\
\hline Alanine transaminase & 9 & $U / L$ \\
\hline Aspartate transaminase & 12 & $U / L$ \\
\hline ү-glutamyltransferase & 10 & $U / L$ \\
\hline Alkaline phosphatase & 244 & $U / L$ \\
\hline Creatine kinase & 41 & $U / L$ \\
\hline Lactate dehydrogenase & 156 & U/L \\
\hline Total protein & 6.9 & $\mathrm{~g} / \mathrm{dL}$ \\
\hline Albumin & 4 & $\mathrm{~g} / \mathrm{dL}$ \\
\hline Urea nitrogen & 52.1 & $\mathrm{mg} / \mathrm{dL}$ \\
\hline Creatinine & 7.28 & $\mathrm{mg} / \mathrm{dL}$ \\
\hline Uric acid & 10.8 & $\mathrm{mg} / \mathrm{dL}$ \\
\hline Sodium & 141 & $\mathrm{mEq} / \mathrm{L}$ \\
\hline Potassium & 4.3 & $\mathrm{mEq} / \mathrm{L}$ \\
\hline Chloride & 104 & $\mathrm{mEq} / \mathrm{L}$ \\
\hline Inorganic phosphorus & 6 & $\mathrm{mg} / \mathrm{dL}$ \\
\hline Calcium & 8.1 & $\mathrm{mg} / \mathrm{dL}$ \\
\hline Corrected calcium & 8.1 & $\mathrm{mg} / \mathrm{dL}$ \\
\hline Iron & 48 & $\mu \mathrm{g} / \mathrm{dL}$ \\
\hline Total iron binding capacity & 181 & $\mu \mathrm{g} / \mathrm{dL}$ \\
\hline Iron saturation & 27 & $\%$ \\
\hline Ferritin & 1736.1 & $\mathrm{ng} / \mathrm{mL}$ \\
\hline Magnesium & 2.4 & $\mathrm{mg} / \mathrm{dL}$ \\
\hline Triglycerides & 130 & $\mathrm{mg} / \mathrm{dL}$ \\
\hline Low-density lipoprotein cholesterol & 75 & $\mathrm{mg} / \mathrm{dL}$ \\
\hline Blood sugar & 271 & $\mathrm{mg} / \mathrm{dL}$ \\
\hline Glycoalbumin & 24.4 & $\%$ \\
\hline Parathyroid hormone-intact & 358 & $\mathrm{pg} / \mathrm{mL}$ \\
\hline
\end{tabular}

Table 1 Results of laboratory findings from March 2016 (Continued)

\begin{tabular}{lll}
\hline B2-microglobulin & 23.4 & $\mathrm{mg} / \mathrm{L}$ \\
After dialysis session & & \\
Serology & & \\
Albumin & 4.5 & $\mathrm{~g} / \mathrm{dL}$ \\
Urea nitrogen & 13.9 & $\mathrm{mg} / \mathrm{dL}$ \\
Creatinine & 2.22 & $\mathrm{mg} / \mathrm{dL}$ \\
Sodium & 141 & $\mathrm{mEq} / \mathrm{L}$ \\
Potassium & 2.8 & $\mathrm{mEq} / \mathrm{L}$ \\
Chloride & 102 & $\mathrm{mEg} / \mathrm{L}$ \\
Inorganic phosphorus & 2.1 & $\mathrm{mg} / \mathrm{dL}$ \\
Calcium & 8.6 & $\mathrm{mg} / \mathrm{dL}$ \\
Atrial natriuretic peptide & 34.6 & $\mathrm{pg} / \mathrm{mL}$ \\
\hline
\end{tabular}

developed ESA, a third-generation drug known as epoetin $\beta$ pegol or CERA, has a methoxy polyethylene glycol chain integrated via amide bonds between the $\mathrm{N}$ terminal amino group of lysine using a succinimidyl butanoic acid linker [20]. CERA has the longest duration of action among all ESAs. Every ESA is widely used for patients undergoing dialysis, and the costs are included in a bundled dialysis treatment payment in Japan and the United States [21]. The use of ESAs among patients undergoing hemodialysis is summarized in Table 2 [22].

Switching ESAs from EPO to DPO can resolve transfusion dependency in patients with MDS, as in the present case. In a comparison of the CERA dose before and after switching to DPO, the CERA-equivalent dose of EPO ( $250 \mu \mathrm{g}$ of CERA = 52,000 IU of EPO) was lower than the DPO-equivalent dose of EPO $(240 \mu \mathrm{g}$ of $\mathrm{DPO}=60,000 \mathrm{IU}$ of EPO) [22]. With respect to the mechanism of action of ESAs, there are some differences between EPO and DPO. For example, although DPO exhibits the same mechanism of action as EPO [23], DPO has a threefold longer circulating half-life and is more potent in vivo than EPO [24]. This longer circulating half-life provides the benefit of DPO via preventing apoptosis and sustaining erythroid differentiation of erythroid precursors [25-27] as well as inducing globin gene expression and specifically promoting late erythroid differentiation in cooperation with GATA-1 [28]. Similar differences may also exist between DPO and CERA because CERA has a considerably longer half-life (139 h) than DPO (21 h) [29]. Because these differences do not depend on hemodialysis, switching ESAs from EPO to DPO can be expected to be effective in patients who are not undergoing hemodialysis.

Although switching to DPO from CERA has been reported in a case of pure red cell aplasia in a hemodialysis patient [30], switching to CERA from DPO has not been documented. However, the possibility of switching to 


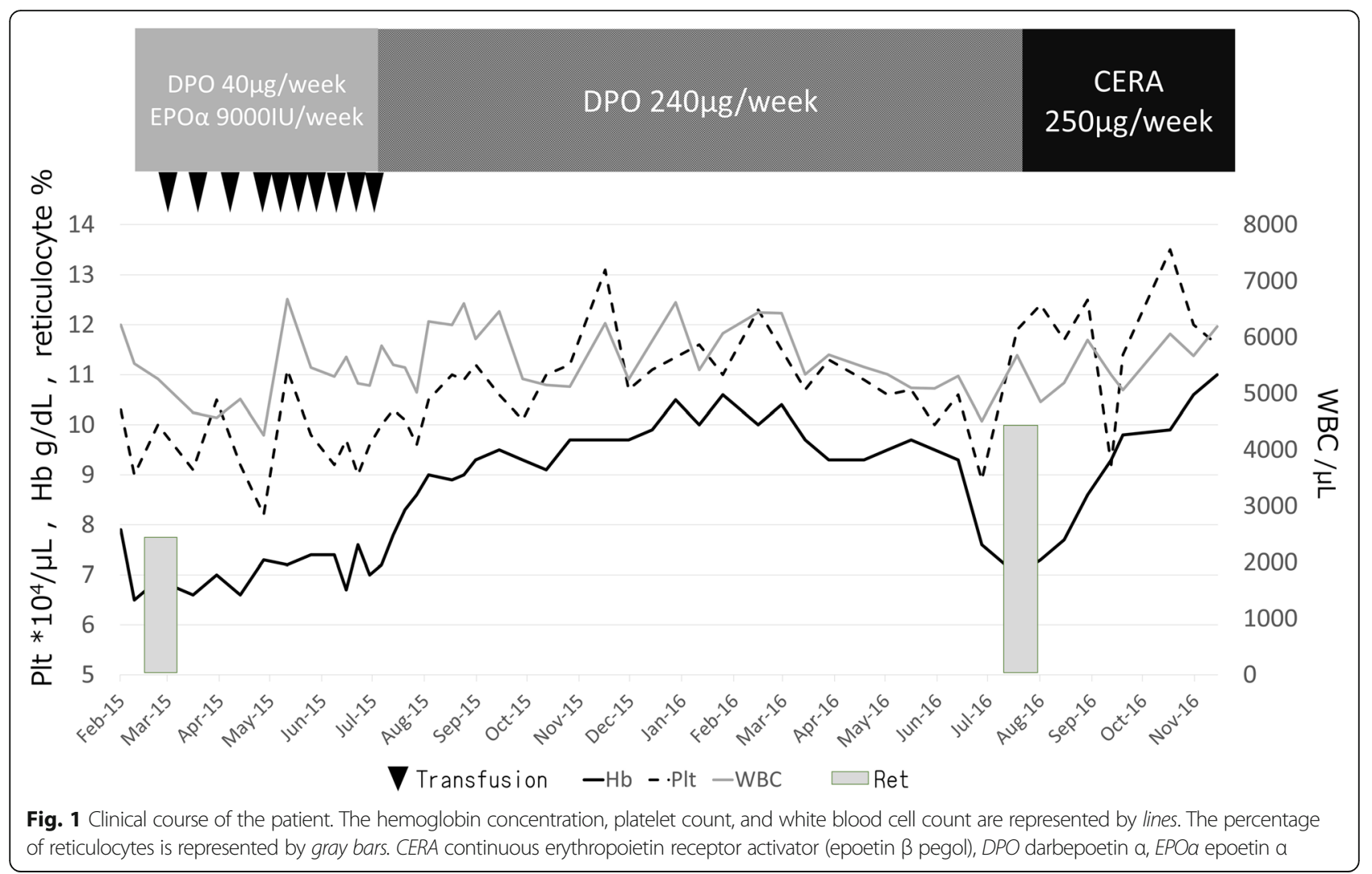

CERA, which is associated with a very low rate of adverse events [31], can be considered among patients who develop a loss of response to DPO. This is a unique aspect of this case compared with previous reports in the literature. Although DPO is the first-choice supportive therapy in patients with MDS [32], we consider CERA to be the second-choice therapy before lenalidomide. Several studies have shown overall response rates ranging from 25 to $35 \%$ with an expected duration of response of 12 to 18 months [33-35]. The combination of lenalidomide and EPO significantly improves the erythroid response over lenalidomide alone in patients with lower-risk non-del5q MDS with ESA-resistant anemia [36]. In one study, however, grade $3 / 4$ adverse events such as neutropenia (30\%) and thrombocytopenia (25\%) were common among patients using lenalidomide [37].

\section{Conclusions}

In patients with low-risk MDS who have stopped responding to DPO for anemia, switching to CERA might help to avoid transfusion; however, the accumulation of more experience and knowledge of the use of CERA in patients with MDS is necessary. We hope that physicians who read this report will consider CERA as an alternative treatment option for anemia caused by MDS and that they will report case series involving CERA as the second option for treatment of MDSinduced anemia.

Table 2 Use of erythropoiesis-stimulating agents among patients undergoing hemodialysis

\begin{tabular}{llll}
\hline & Japan & United States & Europe \\
\hline Available ESAs in HD therapy & $\begin{array}{l}\text { Epoetin, darbepoetin, } \\
\text { epoetin } \beta \text { pegol }\end{array}$ & Epoetin, darbepoetin, & $\begin{array}{l}\text { Epoetin, darbepoetin, } \\
\text { epoetin } \beta \text { pegol }\end{array}$ \\
Target range of hemoglobin $\beta$ pegol & $10-12 \mathrm{~g} / \mathrm{dL}$ & $10-12 \mathrm{~g} / \mathrm{dL}$ \\
Payment of ESAs among HD patients & $10-12 \mathrm{~g} / \mathrm{dL}$ & Bundle & Per dose \\
Mean (median) of ESAs dose in a week & Bundle & $13,834(8655)$ & $8216(6249)$ \\
\hline
\end{tabular}

ESA dose conversions: subcutaneous epoetin $\times 1.15$; darbepoetin (intravenous or subcutaneous) $\times 250$ units/mg; and epoetin $\beta$ pegol (intravenous or subcutaneous) $\times 208$ units $/ \mathrm{mg}$

ESA erythropoiesis-stimulating agents, $H D$ hemodialysis 


\section{Abbreviations}

CERA: Continuous erythropoietin receptor activator; DPO: Darbepoetin a EPO: Erythropoietin; ESAs: Erythropoiesis-stimulating agents; MDS: Myelodysplastic syndrome

\section{Acknowledgements}

We thank Angela Morben, DVM, ELS, from Edanz Group (www.edanzediting.com/ac) for editing a draft of this manuscript.

\section{Funding}

Preparation of this manuscript was supported by a divisional fund only.

\section{Availability of data and materials}

Data and materials that do not reveal patient identity are available and can be requested directly from the corresponding author.

\section{Authors' contributions}

TI drafted the initial version of the manuscript and participated in patient management. TK and HN contributed to patient management as nephrologists and helped to draft the manuscript. HT contributed to patient management as a hematologist. All authors read and approved the final version of the manuscript.

\section{Ethics approval and consent to participate}

Our institutional review board (IRB) approved this report (IRB Log Number: 8).

\section{Consent for publication}

Written informed consent was obtained from the patient for publication of this case report and any accompanying images. A copy of the written consent is available for review by the Editor-in-Chief of this journal.

\section{Competing interests}

The authors declare that they have no competing interests.

\section{Publisher's Note}

Springer Nature remains neutral with regard to jurisdictional claims in published maps and institutional affiliations.

\section{Author details}

${ }^{1}$ Department of Healthcare Epidemiology, Kyoto University Graduate School of Medicine and Public Health, Yoshida Konoe-cho, Sakyo-ku, Kyoto

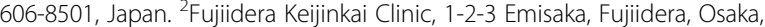
Japan. ${ }^{3}$ Division of Hematology, Yao Municipal Hospital, 1-3-1 Ryugecho, Yao, Osaka, Japan.

Received: 8 May 2017 Accepted: 20 September 2017

Published online: 19 October 2017

\section{References}

1. Santini V. Treatment of low-risk myelodysplastic syndrome: hematopoietic growth factors erythropoietins and thrombopoietins. Semin Hematol. 2012; 49(4):295-303.

2. Cogle CR, Craig BM, Rollison DE, List AF. Incidence of the myelodysplastic syndromes using a novel claims-based algorithm: high number of uncaptured cases by cancer registries. Blood. 2011;117(26):7121-5.

3. Greenberg PL, Tuechler H, Schanz J, Sanz G, Garcia-Manero G, Sole F, Bennett JM, Bowen D, Fenaux P, Dreyfus F, et al. Revised international prognostic scoring system for myelodysplastic syndromes. Blood. 2012; 120(12):2454-65.

4. Balducci L. Transfusion independence in patients with myelodysplastic syndromes: impact on outcomes and quality of life. Cancer. 2006;106(10):2087-94.

5. Sekeres MA, Schoonen WM, Kantarjian H, List A, Fryzek J, Paquette R, Maciejewski JP. Characteristics of US patients with myelodysplastic syndromes: results of six cross-sectional physician surveys. J Natl Cancer Inst. 2008;100(21):1542-51.

6. Spiriti MA, Latagliata R, Niscola P, Cortelezzi A, Francesconi M, Ferrari D, Volpe E, Clavio M, Grossi A, Reyes MT, et al. Impact of a new dosing regimen of epoetin alfa on quality of life and anemia in patients with lowrisk myelodysplastic syndrome. Ann Hematol. 2005;84(3):167-76.

7. Park S, Kelaidi C, Sapena R, Vassilieff D, Beyne-Rauzy O, Coiteux V, Vey N, Ravoet $C$, Cheze $S$, Rose $C$, et al. Early introduction of ESA in low risk MDS patients may delay the need for RBC transfusion: a retrospective analysis on 112 patients. Leuk Res. 2010;34(11):1430-6.

8. Greenberg PL, Sun Z, Miller KB, Bennett JM, Tallman MS, Dewald G, Paietta E, van der Jagt R, Houston J, Thomas ML, et al. Treatment of myelodysplastic syndrome patients with erythropoietin with or without granulocyte colony-stimulating factor: results of a prospective randomized phase 3 trial by the Eastern Cooperative Oncology Group (E1996). Blood. 2009;114(12):2393-400.

9. Jadersten M, Malcovati L, Dybedal I, Della Porta MG, Invernizzi R, Montgomery SM, Pascutto C, Porwit A, Cazzola M, Hellstrom-Lindberg E. Erythropoietin and granulocyte-colony stimulating factor treatment associated with improved survival in myelodysplastic syndrome. J Clin Oncol. 2008;26(21):3607-13.

10. Park S, Grabar S, Kelaidi C, Beyne-Rauzy O, Picard F, Bardet V, Coiteux V, Leroux G, Lepelley P, Daniel MT, et al. Predictive factors of response and survival in myelodysplastic syndrome treated with erythropoietin and GCSF: the GFM experience. Blood. 2008:111(2):574-82.

11. Santini V. Clinical use of erythropoietic stimulating agents in myelodysplastic syndromes. Oncologist. 2011;16 Suppl 3:35-42.

12. Buccisano F, Piccioni AL, Nobile C, Criscuolo M, Niscola P, Tatarelli C, Fianchi L, Villiva N, Neri B, Carmosino I, et al. Real-life use of erythropoiesisstimulating agents in myelodysplastic syndromes: a "Gruppo Romano Mielodisplasie (GROM)" multicenter study. Ann Hematol. 2016;95(7):1059-65.

13. Savic A, Marisavljevic D, Kvrgic V, Stanisavljevic N. Validation of the Revised International Prognostic Scoring System for patients with myelodysplastic syndromes. Acta Haematol. 2014;131(4):231-8.

14. Gotlib J, Lavori P, Quesada S, Stein RS, Shahnia S, Greenberg PL. A Phase II intra-patient dose-escalation trial of weight-based darbepoetin alfa with or without granulocyte-colony stimulating factor in myelodysplastic syndromes. Am J Hematol. 2009;84(1):15-20.

15. Kelaidi C, Beyne-Rauzy O, Braun T, Sapena R, Cougoul P, Adès L, Pillard F, Lambert C, Charniot J, Guerci A. High response rate and improved exercise capacity and quality of life with a new regimen of darbepoetin alfa with or without filgrastim in lower-risk myelodysplastic syndromes: a phase II study by the GFM. Ann Hematol. 2013;92(5):621-31.

16. Musto P, Lanza F, Balleari E, Grossi A, Falcone A, Sanpaolo G, Bodenizza C, Scalzulli PR, La Sala A, Campioni D, et al. Darbepoetin alpha for the treatment of anaemia in low-intermediate risk myelodysplastic syndromes. Br J Haematol. 2005;128(2):204-9.

17. Stasi R, Abruzzese E, Lanzetta G, Terzoli E, Amadori S. Darbepoetin alfa for the treatment of anemic patients with low- and intermediate-1-risk myelodysplastic syndromes. Ann Oncol. 2005;16(12):1921-7.

18. Eschbach JW, Egrie JC, Downing MR, Browne JK, Adamson JW. Correction of the anemia of end-stage renal disease with recombinant human erythropoietin. N Engl J Med. 1987:316(2):73-8.

19. Macdougall IC, Gray SJ, Elston O, Breen C, Jenkins B, Browne J, Egrie J. Pharmacokinetics of novel erythropoiesis stimulating protein compared with epoetin alfa in dialysis patients. J Am Soc Nephrol. 1999;10(11):2392-5.

20. Besarab A, Salifu MO, Lunde NM, Bansal V, Fishbane S, Dougherty FC, Beyer U. Efficacy and tolerability of intravenous continuous erythropoietin receptor activator: a 19-week, phase II, multicenter, randomized, open-label, dose-finding study with a 12-month extension phase in patients with chronic renal disease. Clin Ther. 2007;29(4):626-39.

21. Wish JB. Anemia management under a bundled payment policy for dialysis: a preview for the United States from Japan. Kidney Int. 2011;79(3):265-7.

22. Fuller DS, Bieber BA, Pisoni RL, Li Y, Morgenstern H, Akizawa T, Jacobson SH, Locatelli F, Port FK, Robinson BM. International comparisons to assess effects of payment and regulatory changes in the United States on anemia practice in patients on hemodialysis: the dialysis outcomes and practice patterns study. J Am Soc Nephrol. 2016;27(7):2205-15.

23. Locatelli F, Vecchio LD. Darbepoetin alfa. Amgen. Curr Opin Investig Drugs. 2001;2(8):1097-104.

24. Egrie JC, Dwyer E, Browne JK, Hitz A, Lykos MA. Darbepoetin alfa has a longer circulating half-life and greater in vivo potency than recombinant human erythropoietin. Exp Hematol. 2003;31(4):290-9.

25. Koury MJ, Bondurant MC. Erythropoietin retards DNA breakdown and prevents programmed death in erythroid progenitor cells. Science. 1990; 248(4953):378-81.

26. Claessens YE, Park S, Dubart-Kupperschmitt A, Mariot V, Garrido C, Chretien S, Dreyfus F, Lacombe C, Mayeux P, Fontenay M. Rescue of early-stage myelodysplastic syndrome-deriving erythroid precursors by the ectopic 
expression of a dominant-negative form of FADD. Blood. 2005;105(10): 4035-42.

27. Zermati Y, Garrido C, Amsellem S, Fishelson S, Bouscary D, Valensi F, Varet B, Solary $E_{1}$ Hermine $\mathrm{O}$. Caspase activation is required for terminal erythroid differentiation. J Exp Med. 2001;193(2):247-54.

28. Frisan E, Vandekerckhove J, de Thonel A, Pierre-Eugene C, Sternberg A, Arlet JB, Floquet C, Gyan E, Kosmider O, Dreyfus F, et al. Defective nuclear localization of Hsp70 is associated with dyserythropoiesis and GATA-1 cleavage in myelodysplastic syndromes. Blood. 2012;119(6):1532-42.

29. Topf JM. CERA: third-generation erythropoiesis-stimulating agent. Expert Opin Pharmacother. 2008;9(5):839-49.

30. Nagai K, Yamagata K. Use of darbepoetin alfa for myelodysplastic syndrome coincident with chronic kidney disease. CEN Case Rep. 2016;5(1):117-8.

31. Kuwahara M, Hasumi S, Mandai S, Tanaka T, Shikuma S, Akita W, Mori Y, Sasaki $\mathrm{S}$. Effects of three kinds of erythropoiesis-stimulating agents on renal anemia in Japanese non-dialysis chronic kidney disease patients. Clin Exp Nephrol. 2014;18(5):755-62.

32. Hellstrom-Lindberg $\mathrm{E}$, van de Loosdrecht A. Erythropoiesis stimulating agents and other growth factors in low-risk MDS. Best Pract Res Clin Haematol. 2013;26(4):401-10.

33. Thepot S, Ben Abdelali R, Chevret S, Renneville A, Beyne-Rauzy O, Prebet T, Park S, Stamatoullas A, Guerci-Bresler A, Cheze S, et al. A randomized phase II trial of azacitidine +/- epoetin-beta in lower-risk myelodysplastic syndromes resistant to erythropoietic stimulating agents. Haematologica. 2016;101(8):918-25.

34. Lyons RM, Cosgriff TM, Modi SS, Gersh RH, Hainsworth JD, Cohn AL, McIntyre HJ, Fernando IJ, Backstrom JT, Beach CL. Hematologic response to three alternative dosing schedules of azacitidine in patients with myelodysplastic syndromes. J Clin Oncol. 2009;27(11):1850-6.

35. Musto P, Maurillo L, Spagnoli A, Gozzini A, Rivellini F, Lunghi M, Villani O, Aloe-Spiriti MA, Venditti A, Santini V, et al. Azacitidine for the treatment of lower risk myelodysplastic syndromes : a retrospective study of 74 patients enrolled in an Italian named patient program. Cancer. 2010;116(6):1485-94.

36. Toma A, Kosmider O, Chevret S, Delaunay J, Stamatoullas A, Rose C, BeyneRauzy O, Banos A, Guerci-Bresler A, Wickenhauser S, et al. Lenalidomide with or without erythropoietin in transfusion-dependent erythropoiesisstimulating agent-refractory lower-risk MDS without 5 q deletion. Leukemia 2016;30(4):897-905.

37. Raza A, Reeves JA, Feldman EJ, Dewald GW, Bennett JM, Deeg HJ, Dreisbach L, Schiffer CA, Stone RM, Greenberg PL, et al. Phase 2 study of lenalidomide in transfusion-dependent, low-risk, and intermediate-1 risk myelodysplastic syndromes with karyotypes other than deletion 5q. Blood. 2008;111(1):86-93.

\section{Submit your next manuscript to BioMed Central and we will help you at every step:}

- We accept pre-submission inquiries

- Our selector tool helps you to find the most relevant journal

- We provide round the clock customer support

- Convenient online submission

- Thorough peer review

- Inclusion in PubMed and all major indexing services

- Maximum visibility for your research

Submit your manuscript at www.biomedcentral.com/submit

CBiomed Central 